PYTHAGORAS: Jurnal Pendidikan Matematika

Volume 10 - Nomor 2, Desember 2015, (189-200)

Available online at: http://journal.uny.ac.id/index.php/pythagoras

\title{
Perbandingan Keefektifan Pembelajaran GI dan Problem Solving Ditinjau dari Prestasi Belajar Peluang, Kemampuan Penalaran, dan Sikap Siswa terhadap Matematika
}

\author{
Sardin \\ Pendidikan Matematika, Universitas Dayanu Ikhsanuddin. Jalan Yos Sudarso No.43, Sulawesi \\ Tenggara, Indonesia. Email: sardinppsunypmath@gmail.com
}

\begin{abstract}
Abstrak
Penelitian ini bertujuan untuk mendeskripsikan keefektifan pembelajaran guided inquiry dan problem solving, serta perbedaan kedua pembelajaran tersebut yang ditinjau dari prestasi belajar peluang, kemampuan penalaran siswa, dan sikap siswa terhadap matematika. Penelitian ini adalah penelitian quasi eksperimen dengan desain pretest-postest nonequivalent comparison-group design. Populasi dalam penelitian ini adalah seluruh siswa Kelas XI SMA Negeri 2 Baubau yang dikelompokan sebanyak 10 kelas. Sampel dalam penelitian ini sebanyak dua kelas yang dipilih secara acak. Untuk mengetahui keefektifan pembelajaran digunakan uji one sample $t$-test; untuk mengetahui perbedaan keefektifan menggunakan uji MANOVA (multivariate tests); untuk mengetahui pembelajaran mana yang lebih efektif menggunakan uji independent sample t-test. Adapun hasil penelitian ini adalah: (1) pendekatan pembelajaran guided inquiry dan pembelajaran problem solving masing-masing efektif ditinjau dari prestasi belajar, kemampuan penalaran siswa, dan sikap siswa terhadap matematika, (2) pendekatan pembelajaran guided inquiry sama efektifnya dengan pembelajaran problem solving ditinjau dari prestasi belajar dan sikap siswa terhadap matematika, dan (3) pendekatan pembelajaran guided inquiry lebih efektif dari pada pembelajaran problem solving ditinjau dari kemampuan penalaran siswa.
\end{abstract}

Kata Kunci: pembelajaran guided inquiry, pembelajaran problem solving, prestasi belajar, penalaran matematika, dan sikap siswa terhadap matematika

\section{Comparison of Effectiveness Between GI Learning Approach and Problem Solving on Learning Achievement Probability, Reasoning Ability and Attitude Toward Mathematics}

\begin{abstract}
This study aimed to describe the effectiveness of guided inquiry learning and problem solving, as well as those learning a second difference is in terms of achievement of learning opportunities, reasoning ability of students, and students' attitudes toward mathematics. This research is a quasiexperimental design with pretest-posttest nonequivalent comparison-group design. The population in this study were all students of Class XI SMAN 2 Baubau to be grouped as much as 10 classes. The sample in this study were two randomly selected classes. To determine the effectiveness of study used a test of one sample t-test; to determine differences in the effectiveness of using test MANOVA (multivariate tests); to know which one is more effective learning using independent sample t-test test. The results of this study are: (1) guided inquiry approach to learning and teaching problem solving each effective in terms of achievement of learning, reasoning ability of students, and students' attitudes toward mathematics, (2) guided inquiry learning approach is as effective as the learning problem solving in terms of achievement learning and students 'attitudes toward mathematics, and 3) guided inquiry learning approach is more effective than learning problem solving in terms of students' mathematical reasoning abilities.
\end{abstract}

Keywords: guided inquiry learning, problem solving learning, academic achievement, mathematical reasoning, and students' attitudes toward mathematics

How to Cite Item: Sardin, S. (2015). Perbandingan keefektifan pembelajaran guided inquiry dan problem solving ditinjau dari prestasi belajar peluang, kemampuan penalaran, dan sikap siswa terhadap matematika. PYTHAGORAS: Jurnal Pendidikan $\quad$ Matematika, $10(2), \quad 189-200$. doi:http://dx.doi.org/10.21831/pg.v10i2.9158 


\section{Pythagoras, 10 (2), Desember 2015 - 190}

Sardin

\section{PENDAHULUAN}

Matematika merupakan salah satu ilmu dasar yang mempunyai peranan penting baik dalam kehidupan sehari-hari maupun dalam pengembangan ilmu dan teknologi. Begitu pentingnya belajar matematika menuntut para pendidiknya untuk menguasai pendekatan atau metode belajar yang baik. Matematika dengan struktur yang kompleks menuntut para pendidik untuk membelajarkan dengan metode yang efektif. Selain itu, kemampuan penguasaan matematika siswa juga diharapkan memiliki kemampuan berpikir kritis, berpikir logis, kemampuan penalaran yang tinggi, sikap positif serta prestasi yang mumpuni sebagai bekal kehidupan yang akan datang.

Dalam rangka mendorong kemampuan peserta didik yang menghasilkan karya kontekstual, baik individual maupun kelompok maka sangat disarankan menggunakan pendekatan pembelajaran yang menghasilkan karya berbasis pemecahan masalah (Permen 65 tahun 2013). Dalam menghasilkan peserta didik yang kompeten diperlukan peran guru dalam pembelajaran. Peran guru di dalam kelas dapat mengefektifkan pembelajaran. Keefektifan pembelajaran di dalam kelas dapat mencapai dua hasil penting yakni; a) prestasi siswa yang meningkat, dan b) motivasi siswa yang bertambah (Eggen, \& Kauchak (2009, p.39).

Pembelajaran matematika yang efektif dapat menciptakan suasana belajar yang aktif sehingga dapat mempengaruhi pikiran siswa. Dalam rangka mendukung prestasi belajar matematika siswa (NCTM, 2000, p.7) menetapkan "five standards address the processes of problem solving, reasoning and proof, connections, communication, and representation". ada lima standar yang harus dimiliki oleh siswa yakni kemampuan pemecahan masalah, kemampuan penalaran dan bukti, kemampuan koneksitas, kemampuan komunikasi, dan kemampuan representasi.

Salah satu krisis terbesar sistem pendidikan di banyak negara, khususnya negara berkembang adalah masalah rendahnya prestasi akademik (Dehyadegary, et al, 2012, p.823). Hal ini pun sejalan dengan fakta yang terjadi di tempat penelitian SMA Negeri 2 Baubau pada materi statistika dan peluang. Kemampuan penguasaan materi statistik dan peluang di SMA Negeri 2 Baubau berdasarkan BSNP adalah sebagai berikut:
Tabel 1. Persentase Penguasaan Materi

Statistika dan Peluang Tahun 2012/2013.

\begin{tabular}{ll}
\hline Kemampuan yang diuji & Sekolah \\
\hline Mengolah, menyajikan, \& menafsirkan & \\
data, mampu memahami kaidah penca- & \\
cahan, permutasi, kombinasi, \& peluang & $36,51 \%$ \\
kejadian serta mampu menerapkannya & \\
dalam pemecahan masalah. & \\
\hline
\end{tabular}

Berdasarkan Tabel 1 kemampuan penguasaan materi peluang masih jauh dari kriteria ketuntasan minimal yang biasa ditetapkan disekolah sehingga perlu ditingkatkan.

Rendahnya penguasaan materi ikut mempengaruhi kemampuan penalaran siswa. Penalaran merupakan salah satu kemampuan standar yang harus dimiliki siswa pada pembelajaran matematika. Penalaran (jalan pikiran atau reasoning) merupakan proses berpikir yang berusaha menghubung-hubungkan fakta-fakta yang diketahui menuju suatu kesimpulan (Shadiq, 2004, p.2). Matematika dan penalaran matematika merupakan dua hal yang tidak terpisahkan karena materi matematika dipahami melalui penalaran dan kemampuan penalaran dilatih melalui belajar matematika. Kegiatan bernalar adalah mengajak siswa untuk berpikir logis, kritis, dan rasional. Berpikir yang demikian merupakan bagian dari perwujudan perila$\mathrm{ku}$ belajar yang berkaitan dengan pemecahan masalah, dimana siswa dituntut untuk berpikir secara rasional untuk mengetahui sebab akibat, cara menganalisis dan membuat kesimpulan (Syah, 2008, p.120). Namun kenyataan kemampuan penalaran siswa merupakan suatu permasalahan di SMA Negeri 2 Baubau. Hal ini berdasarkan nilai semester ganjil tahun ajaran 2014/2015 yakni sebanyak 56\% siswa dengan penalaran rendah, $33 \%$ siswa dengan penalaran sedang, dan $21 \%$ siswa dengan penalaran tinggi. Sebagian besar siswa masih kurang dalam membuktikan suatu pernyataan sahih dan penarikan kesimpulan.

Upaya lain yang perlu ditingkatkan adalah dengan meningkatkan aspek afektif dari diri siswa.

affect is every bit as important in school (Popham, 1995, p.180). Pandangan positif siswa terhadap matematika merupakan hal penting untuk meningkatkan prestasi belajar. affective objectives were recognise to be important as both ends and means in the overall school process (Gable, 1986, p.2). Aspek afektif turut menentukan proses, tujuan, serta hasil belajar matematika siswa. Salah satu aspek afektif 
adalah sikap (Gable, 1986, p.4). Sikap siswa terhadap matematika memberikan pengaruh terhadap keberhasilan belajar matematika. Sikap siswa terhadap matematika has been a factor that is known to influence students' achievement in mathematics (Mohamed \& Waheed, 2011, p.277). Maksudnya bahwa sikap siswa terhadap matematika dapat berpengaruh pada prestasi belajar siswa. Sikap positif siswa terhadap pelajaran matematika akan membuat siswa bersemangat dalam belajar. Namun dalam kenyataannya di tempat penelitian masih jauh dari harapan. Hal ini berdasarkan hasil observasi awal dengan memberikan angket sikap siswa terhadap matematika diperoleh sebanyak $63,22 \%$ siswa dengan sikap rendah, 26,67\% siswa dengan sikap sedang, $10,11 \%$ siswa dengan sikap tinggi. Bedasarkan hasil angket sikap siswa terhadap matematika tersebut yang lebih dari 50\% siswa dengan sikap rendah.

Matematika sekolah dapat dipandang sebagai aktifitas antara guru dan siswa. Guru mengajarkan pengetahuan matematika yang dimilikinya kepada siswa. Proses guru mengkomunikasikan pengetahuan yang dimilikinya menjadi suatu hal yang tidak gampang. Guru harus mampu menciptakan suasana belajar yang nyaman di dalam kelas. Pembelajaran dengan situasi-situasi yang baik akan mampu mengefektifkan penguasaan pengetahuan dan pemahaman terhadap materi yang diajarkan. Mengkondisikan siswa menjadi student centre menjadi pembelajaran yang menarik bagi siswa karna siswa akan bereksplorasi dengan ide-idenya untuk membangun pengetahuannya dalam menemukan konsep baru. Hal ini diharapkan dapat meningkatkan prestasi belajar, kemampuan penalaran, serta merubah asumsi negatif terhadap matematika.

Salah satu pendekatan pembelajaran yang mampu mengatasi masalah ketiga aspek tersebut di atas adalah dengan menerapkan pendekatan pembelajaran guided inquiry. Inquiry diartikan sebagai penemuan. (Hosnan, 2014, p.341) \& (Majid, 2013, p.160). Selanjutnya guided inquiry diartikan sebagai penemuan terbimbing. Pembelajaran guided inquiry adalah pembelajaran yang berpusat pada siswa dengan mengaktifkan kegiatan siswa untuk menemukan konsep dengan cara memberikan pertanyaan-pertanyaan yang ilmiah kepada siswa, lalu siswa mencari jawaban sendiri dengan mengarahkan seluruh kemampuan belajarnya (Markaban, 2008, p.11; Eggen \& Kauchak, 2012, p.177; Hosnan, 2014, p.341). Pada kegiatan mencari informasi terse- but siswa menelaah semuan informasi yang ada secara sistematis, logis, analisis yang mengarah pada satu kesimpulan berdasarkan data yang meyakinkan. Instruksi pembelajaran guided inquiry membantu siswa develop research competency and subject knowledge as well as foster motivation, reading comprehension, language development, writing ability, cooperative learning, and social skill (Kuhlthau, Maniotes, \& Caspari, 2007,p.2). Maksudnya adalah guided inquiry membantu siswa mengembangkan kompetensi penyelidikan dan pengetahuan tentang subjek maupun mengembangkan motivasi, kemampuan membaca, pengembangan bahasa, kemampuan menulis, belajar kelompok, dan kemampuan bermasyarakat. Selain itu, kegiatan pembelajaran guided inquiry dapat membantu siswa dalam mengembangkan sikap percaya diri (Hosnan, 2014, p.341).

Pembelajaran inquiry is effective for preparing students to think deeply about a subject (Kuhlthau, Maniotes, \& Caspari, 2007, p.5). Pembelajaran guided inquiry (penemuan terbimbing) efektif digunakan dalam mengembangkan prestasi belajar peluang, kemampuan penalaran, dan sikap siswa terhadap matematika. Hal ini tercermin dalam langkah-langkah pembelajaran yang terdiri dari empat fase (Eggen \& Kauchak, 2012,p.190) yakni sebagai berikut: Fase pendahuluan ;Guru berusaha menarik perhatian siswa dan menetapkan fokus pembelajaran dengan memberikan kerangka kerja konseptual. Fase terbuka; Guru memberi siswa contoh dan meminta siswa untuk mengamati dan membandingkan contoh-contoh. Fase ini diberikan dengan tujuan untuk mendorong keterlibatan siswa dan memastikan keberhasilan awal mereka. Fase konvergen; Guru memberikan pertanyaan-pertanyaan yang lebih spesifik yang dirancang untuk membimbing siswa mencapai pemahaman tentang konsep atau generalisasi. Fase penutup dan penerapan; Guru membimbing siswa memahami definisi suatu konsep atau pernyataan generalisasi dan siswa menerapkan pemahaman mereka kedalam konteks baru. Pada langkah ini juga siswa diberi kesempatan untuk mempresentasikan hasil kerja kelompoknya.

Pembelajaran lain yang digunakan dalam penelitian ini adalah pembelajaran problem solving. Pendekatan problem solving merupakan real-life and simulated problem situations provide context and reason for learning mathematics (Lester \& Schroeder dalam Kennedy, Tipps, \& Johnson, 2008, p.19). Pendekatan problem solving merupakan pendekatan yang 
menggunakan masalah kehidupan sehari-hari dan situasi masalah yang disimulasi sebagai kontek dan alasan untuk belajar matematika. Pendekatan pembelajaran problem solving merupakan suatu metode mengajar yang sifatnya teoritis atau konseptual untuk melatih siswa memecahkan masalah-masalah matematika dengan menggunakan berbagai strategi dan langkah-langkah problem solving (Skemp,1971, pp.227-228).

Pendekatan pembelajaran problem solving sebagai salah satu pendekatan yang menuntut guru untuk membantu siswa dalam belajar memecahkan masalah melalui pengalaman pembelajaran hands-on (Jacobsen, Eggen, \& Kauchak, 2009, p.249). Maksudnya hands-on adalah siswa terlibat langsung dalam penyelesaian permasalahan yang diberikan guru.

Adapun langkah-langkah pembelajaran problem solving adalah sebagai berikut: Mengidentifikasi masalah (Posamentier, Smith \& Steplman, 2010, p.108), (Jacobsen, Eggen, \& Kauchak, 2009, pp.250-252) \& Forgan (2003, p.3). Menentukan strategi penyelesaian masalah yang relevan. (Jacobsen, Eggen, \& Kauchak, 2009, pp.250-252) \& Forgan (2003, p.3). Strategi penyelesaian dengan langkah Polya (1973, p.xvi-xvii) yakni; (1). memahami masalah, (2). merencanakan pemecahan masalah, (3). menyelesaikan masalah sesuai dengan rencana, (4). memeriksa kembali hasil yang diperoleh; Presentasi hasil diskusi; Mengevaluasi hasil belajar (Posamentier, Smith \& Steplman, 2010, p.108), (Jacobsen, Eggen, \& Kauchak, 2009, pp.250-252) \& Forgan (2003, p.3).

Pendekatan pembelajaran yang efektif diterapkan dalam kelas bertujuan untuk mengembangkan kemampuan belajar matematika siswa.

Penerapan pembelajaran guided inquiry dan problem solving diharapkan merupakan solusi efektif untuk meningkatkan prestasi, kemampuan penalaran dan sikap siswa terhadap matematika. Hal ini pun didukung oleh penelitian relevan yang dilakukan oleh Matthew \& Kenneth (2013, p.135), Zukri (2013, p.ii), Ihedioha \& Osu (2013, p.33), Ike (2014, p.2), Ergül, et.al (2011, p.48), Zahman (2012: p.ii), Saputra (2012, p. ii) \& Junaidi (2012, p.ii) yang menyimpulkan bahwa pendekatan pembelajaran guided inquiry dan pembelajaran problem solving masing-masing efektif ditinjau dari prestasi belajar, kemampuan penalaran siswa, dan sikap siswa terhadap matematika.
Penelitian ini selain bertujuan untuk mendiskripsikan keefektifan pendekatan pembelajaran yang digunakan. Penelitian ini juga bertujuan untuk memberikan pengalaman belajar yang lain dari biasanya. Siswa diberikan pengalaman belajar berkelompok. Siswa diberikan pengalaman untuk menemukan sendiri konsep materi yang dipelajari. Siswa diberi LKS sebagai panduan belajar yang mengarahkan pikiran siswa untuk menemukan sendiri kesimpulan masalah yang dihadapi. LKS yang disusun berdasarkan karakteristik pembelajaran yang digunakan sehingga hal ini dapat dijadikan sebagai salah satu alternatif pembelajaran di kelas. Khususnya, dalam mengembangkan presatsi belajar peluang (PBP), kemampuan penalaran siswa (KPS), dan sikap siswa terhadap matematika (SSTM).

\section{METODE}

\section{Jenis dan Desain Penelitian}

Penelitian ini adalah penelitian quasi eksperimen dengan desain pretest-postest nonequivalent comparison-group design (Johnson \& Christensen, 2008, p.331). Penelitian ini dilaksanakan di kelas XI SMA Negeri 2 Baubau tahun ajaran 2014/2015 antara bulan FebruariMaret 2015.

\section{Populasi dan Sampel Penelitian}

Populasi dalam penelitian ini adalah sebanyak 587 siswa yang berasal dari 10 kelas XI SMA Negeri 2 Baubau. Di karenakan tidak dapat mengacak siswa untuk dijadikan sampel maka yang di acak adalah kelasnya. Sampel dalam penelitian ini dipilih dua kelas secara acak dari kesepuluh kelas tersebut. Dua kelas yang terpilih adalah kelas XI IPA 3 dan XI IPA 4 sebagai kelas eksperimen yang mempunyai kemampuan awal setara. Kemudian dari dua kelas tersebut dipilih secara acak untuk menentukan jenis pendekatan pembelajaran yang akan digunakan. Diperoleh kelas XI IPA 3 diberi perlakuan dengan pendekatan pembelajaran problem solving dan kelas XI IPA 4 diberi perlakuan dengan pendekatan pembelajaran guided inquiry. Subyek dalam penelitian ini adalah siswa kelas XI IPA 3 dan XI IPA 4 yang masing-masing sebanyak 32 siswa.

\section{Tehnik dan Instrumen Pengumpulan Data}

Tehnik pengumpulan data dalam penelitian ini adalah diberikan instrumen pretest sebelum perlakuan yang terdiri dari seperangkat tes 
prestasi belajar materi peluang, tes kemampuan penaralan siswa, dan akgket sikap siswa terhadap matematika. Hasil pretest dilakukan untuk melihat kemampuan awal siswa. setelah diberikan pretest kemudian diberikan tindakan penelitian dengan menerapkan pembelajaran guided inquiry dan pembelajaran problem solving di masing-masing kelas sampel. Terkahir yakni memberikan instrumen posttest setelah perlakuan. Posttest yang diberikan berupa seperangkat tes prestasi belajar, tes kemampuan penalaran siswa, dan angket sikap siswa terhadap matematika.

\section{Validitas dan Reliabilitas Instrumen}

Instrumen penelitian sebelum digunakan terlebih dahulu divalidasi. Validitas instrument berupa validitas isi dengan meminta saran, masukan, serta pertimbangan dari dua orang dosen ahli (expert judgment) di bidang materi dan evaluasi dan validitas konstruk pada angket. Setelah divalidasi isi instrumen tersebut di ujicobakan dikelas XII. Ujicoba instrumen penelitian ini diberikan kepada siswa kelas XII SMA Negeri 2 Baubau dan siswa kelas XII SMA Negeri 3 Baubau. Pengambilan kelas XII sebagai kelas ujicoba instrumen dengan pertimbangan bahwa kelas tersebut telah mempelajari materi kaidah pencacahan dan peluang. Hasil uji coba instrumen dapat membantu estimasi reliabilitas. Adapun estimasi reliabilitas dari masing masing instrumen adalah sebagai berikut.

Tabel 2. Hasil Estimasi Reliabilitas dengan Cronbach's Alpha

\begin{tabular}{ccc}
\hline Aspek Tinjauan & Pretest & Postest \\
\hline PBP & 0,72 & 0,83 \\
KPS & 0,71 & 0,72 \\
SSTM & & 0,92 \\
\hline
\end{tabular}

\section{Tehnik Analisis Data}

Data penelitian yang dianalisis adalah data tes prestasi belajar, tes kemampuan penalaran, dan angket sikap siswa terhadap matematika sebelum (pretest) dan setelah diberikan perlakuan (posttest). Data diperoleh dari dua kelompok yang berbeda. Data tes dan angket sebelum perlakuan digunakan untuk mengetahui gambaran awal kedua kelompok (kelas). Selanjutnya, data tes dan angket setelah perlakuan digunakan untuk mendeskripsikan keefektifan pendekatan pembelajaran (guided inquiry dan problem solving) dan mendeskripsikan bahwa pendekatan pembelajaran yang mana yang lebih efektif ditinjau dari aspek prestasi belajar, kemampuan penalaran siswa, dan sikap siswa terhadap matematikadi SMA kelas XI.

Deskripsi data dilakukan terhadap semua variabel penelitian. Deskripsi data meliputi nilai rata-rata, standar deviasi, skor minimal, dan skor maksimal, baik untuk data sebelum perlakuan, maupun untuk data setelah perlakuan. Dalam penelitian ini, data yang dideskripsikan adalah data yang berkaitan dengan prestasi belajar, kemampuan penalaran siswa, dan sikap siswa terhadap matematika.

Setelah data dideskripsikan, data-data di analisis kefektifan terhadap pendekatan pembelajaran yang digunakan. Pembelajaran dikatakan efektif apabila nilai rata-rata kelas lebih dari nilai Kriteria Ketuntasan Minimal (KKM). Adapun data KKM dapat dilihat pada Tabel 3.

Tabel 3. Kriteria Ketuntasan Minimal (KKM)

\begin{tabular}{ccc}
\hline Aspek tinjauan & Rentang nilai & KKM \\
\hline PBP & $0,00-100,00$ & 70,00 \\
KPS & $0,00-20,00$ & 13,00 \\
SSTM & $30,00-150,00$ & 115,00 \\
\hline
\end{tabular}

Data-data yang diperoleh sebelum di dianalisis keefektifan terlebih dahulu data berdistribusi normal dan berasal dari matriks varians-kovarian yang homogen. Pemeriksaan uji normalitas menurut Johnson \& Wichern, 2007, pp.183-184) dilakukan dengan menghitung jarak mahalanobis $\left(d_{i}^{2}\right)$. Dengan kriteria pengambilan keputusan yakni apabila sekitar 50\% nilai $d_{i}{ }^{2}<X_{(p ; 0,5)}^{2}$ dikatakan bahwa populasi berdistribusi normal multivariat. Asumsi homogenitas matriks varians kovarians dapat dilakukan dengan menggunakan uji Box's M (Rencher, 1998, pp.138-139). Dengan kriteria keputusan apabila nilai siginifikansi lebih dari 0,05 maka matriks matriks kovarians kedua populasi tersebut homogen. Hasil uji normalitas dan uji homogenitas multivariat dapat dilihat dari Tabel 4.

Tabel 4. Hasil Uji Normalitas Multivariat dan Homogenitas Multivariat

\begin{tabular}{llll}
\hline Uji asumsi & Group & $\boldsymbol{d i}^{2}$ Pretest & $\boldsymbol{d i}^{2}$ Posttest \\
\hline \multirow{2}{*}{ Normalitas } & GI & $46,88 \%$ & $50,00 \%$ \\
& PS & $46,88 \%$ & $53,13 \%$ \\
\hline \multirow{2}{*}{} & & \multicolumn{2}{c}{ Signifikan } \\
\cline { 2 - 4 } & & Pretest & Posttest \\
\hline Homogenitas & GI+PS & 0,168 & 0,715 \\
\hline
\end{tabular}

Persentase uji normalitas pretest dan postest berada disekitar $50,00 \%$. Hal ini mengindikasikan bahwa data sebelum maupun sesudah perlakuan berasal dari populasi yang berdistribusi normal multivariat. Sehingga dapat 
dikatakan bahwa asumsi normalitas multivariat dipenuhi. Nilai siginifikansi Box's M lebih dari 0,05 maka matriks varians kovarians kedua kelompok tersebut homogen.

Uji normalitas multivariat dan homogenitas multivariat terpenuhi. Selanjutnya, dilakukan uji one sample t-test masing-masing kelompok untuk melihat keefektifan pembelajaran yang digunakan. Pengambilan keputusan bahwa apabila nilai signifikansi one tailed $\mathrm{ku}-$ rang dari 0,05 artinya pembelajaran yang digunakan efektif.

Setelah uji keefektifan dengan one sample t-test dilakukan. Langkah selanjutnya adalah melihat perbedaan vektor rata-rata dari kedua pembelajaran tersebut. Uji perbedaan dilakukan terhadap data pretest maupun posttest. Uji perbedaan vektor rata-rata menggunakan uji multivariate $T^{2}$ Hotelling melalui bantuan SPSS 21 for Windows. Dengan kriteria pengambilan keputusan bahwa apabila nilai signifikan $T^{2}$ Hotelling pretest lebih dari 0,05 artinya tidak terdapat perbedaan kemampuan awal siswa dan $T^{2}$ Hotelling posttest kurang dari 0,05 berarti terdapat perbedaan keefektifan pendekatan pembelajaran kedua kelompok. Jika terdapat perbedaan keefektifan pembelajaran kedua kelas, maka dilakukan uji lanjut univariat. Uji lanjut univariat dilakukan dengan uji independent sample t-test. Pengambilan keputusan bahwa apabila nilai signifikansi one tailed kurang dari $0,05 / 3=0,017$ (kriteria benferoni $\frac{\alpha}{p}$ ) maka pembelajaran guided inquiry lebih efektif dari pada pembelajaran problem solving.

\section{HASIL DAN PEMBAHASAN}

\section{Hasil Penelitian}

Hasil yang dianalisis deskripstif adalah data pretest dan posttest kedua kelompok. Hasil analisis deskriptif menunjukkan bahwa pembelajaran matematika dengan pendekatan pembelajaran guided inquiry dan pembelajaran problem solving berdampak positif terhadap prestasi belajar, kemampuan penalaran siswa, dan sikap siswa terhadap matematika. Hal ini terlihat dari hasil pretest dan postetst. Hasil analisis deskriptif dari kedua kelompok dapat dilihat pada Tabel 5.
Tabel 5. Deskripsi rata-rata kelompok PGI dan PPS

\begin{tabular}{ccccc}
\hline & \multicolumn{2}{c}{ PGI } & \multicolumn{2}{c}{ PPS } \\
\cline { 2 - 5 } & Pre & Post & Pre & Post \\
\hline PBP & 44,4 & 79,4 & 44,1 & 76,3 \\
KPS & 10,8 & 17,2 & 11,7 & 14,3 \\
SSTM & 114,2 & 121,7 & 114,1 & 119,7 \\
\hline
\end{tabular}

Berdasarkan Tabel 5 nilai rata-rata semua aspek yang ditinjau mengalami peningkatan yang signifikan. Hasil analisis inferensial dalam penelitian ini terdiri dari hasil uji keefektifan pembelajaran kedua kelompok, uji perbedaan keefektifan pembelajaran antara kedua kelompok, dan uji lanjut univariat untuk melihat pembelajaran mana yang lebih efektif antara kedua kelompok.

Hasil perhitungan keefektifan pendekatan pembelajaran dengan menggunakan uji one sample t-test untuk kelompok guided inquiry dan pembelajaran problem solving dapat dilihat pada Tabel 6.

Tabel 6. Hasil Uji One Sample t-test Kelompok Guided Inquiry dan Problem Solving

\begin{tabular}{lcccc}
\hline \multirow{2}{*}{ Aspek tinjauan } & \multicolumn{2}{c}{ PGI } & \multicolumn{2}{c}{ PPS } \\
\cline { 2 - 5 } & $\mathbf{t}$ & Sig. & t & Sig. \\
\hline PBP & 8,39 & 0,00 & 5,08 & 0,00 \\
KPS & 15,67 & 0,00 & 7,11 & 0,00 \\
SSTM & 6,4 & 0,00 & 3,32 & 0,00 \\
\hline
\end{tabular}

Berdasarkan Tabel 6 menunjukan bahwa nilai signifikan one tailed untuk semua aspek tinjauan baik prestasi belajar, kemampuan penalaran siswa, maupun sikap siswa terhadap matematika lebih kecil dari 0,05. Dengan kata lain pendekatan guided inquiry dan pembelajaran problem solving masing-masing efektif ditinjau dari ketiga aspek tersebut.

Setelah diuji keefektifan kedua kelompok dan hasilnya masing-masing efektif ditinjau dari ketiga aspek. Selanjutnya, uji perbedaan vektor rata-rata kedua kelompok. Adapun hasil signifikansi uji $T^{2}$ Hotelling's pretest dan posttest dapat dilihat pada Tabel 7.

Tabel 7. Nilai Signifikansi Hotelling's Trace Pretest dan Posttest

\begin{tabular}{lll}
\hline & Pretest & Posttest \\
\hline Hotelling's Trace & 0,494 & 0,000 \\
\hline
\end{tabular}

Nilai signifikan sebelum perlakuan lebih dari 0,05 berarti tidak terdapat perbedaan kemampuan awal siswa kedua kelompok. Nilai signifikan setelah perlakuan kurang dari 0,05 berarti terdapat perbedaan keefektifan pembelajaran kedua kelompok ditinjau dari prestasi 


\section{Pythagoras, 10 (2), Desember 2015 - 195}

Sardin

belajar, kemampuan penalaran siswa, dan sikap siswa terhadap matematika. Karena terdapat perbedaan keefektifan pembelajaran kedua kelas ditinjau dari ketiga aspek tersebut maka dilakukan uji lanjut univariat.

Uji lanjut univariat yakni dengan menghitung nilai $t$ atau melihat nilai signifikansi pada uji independent sample t-test. Hasil uji independent sample t-test dapat dilihat pada Tabel 8 .

Tabel 8. Hasil Uji Independent Sample t-test Setelah Perlakuan

\begin{tabular}{ccc}
\hline Aspek tinjauan & $\mathbf{t}$ & Sig one tailed. \\
\hline PBP & 1,881 & 0,033 \\
KPS & 8,242 & 0,000 \\
SSTM & 1,124 & 0,133 \\
\hline
\end{tabular}

Berdasarkan Tabel 8 signifikansi prestasi belajar dan sikap siswa terhadap matematika lebih besar dari 0,017 . Hal ini berarti bahwa pembelajaran guided inquiry sama/tidak lebih efektif dari pada pembelajaran problem solving. Sedangkan nilai signifikansi kemampuan penalaran siswa lebih kecil dari 0,017. Hal ini berarti bahwa pembelajaran guided inquiry lebih efektif dari pendekatan pembelajaran problem solving.

\section{Pembahasan}

Pendekatan pembelajaran guided inquiry efektif ditinjau dari prestasi belajar. Hal ini disebabkan karena pendekatan pembelajaran guided inquiry banyak melibatkan keaktifan siswa. Siswa diarahkan untuk menemukan konsep materi yang sedang dipelajari. Guru berupaya menggiring pemikiran siswa untuk fokus terhadap penyelesaian masalah-masalah yang berkaitan dengan kehidupan sekitarnya. Dari penyelesaian tersebut siswa mampu menyimpulkan suatu konsep umum yang dapat diterapkan pada masalah-masalah lain yang relevan. Semua aktifitas yang dilakukan siswa di bawah bimbingan guru melalui Lembar Kegiatan Siswa (LKS) pada setiap pertemuannya. Dalam pengerjaan LKS siswa membentuk kelompokkelompok kecil yang terdiri dari 4-5 orang siswa. Hal ini menjadi salah satu faktor penyebab pendekatan pembelajaran guided inquiry efektif ditinjau dari prestasi belajar.

Dalam panduan LKS siswa diminta untuk berpikir mengaitkan contoh-contoh dalam kehidupan sehari-hari dengan penyelesaian masalah yang dihadapi. Selain itu, dalam kegiatan guided inquiry siswa terlibat langsung untuk mengamati contoh dan membandingkannya untuk kemudian siswa dapat berhasil menyelesaikan masalah. Siswa diberi pertanyaan-pertanyaa yang lebih spesifik untuk membimbing siswa mencapai pemahaman konsep kemudian membuat generalisasi. Siswa berdiskusi satu sama lain guna menemukan konsep permasalahan. Siswa berdiskusi mulai dari pemahaman konsep dan membuat generalisasai hingga penerapannya pada penyelesaian soal-soal latihan maupun soal-soal Pekerjaan Rumah (PR). Keterlibatan pada kegiatan diskusi siswa memberikan tanggapan, pertanyaan, hingga jawaban terkait dengan apa yang dipresentasikan oleh temantemannya yang lain. Kegiatan diskusi membuat siswa bukan hanya terampil dalam menyelesaikan soal tetapi secara tidak langsung siswa juga mampu menyerap dan memahami masalah yang dihadapi.

Pendekatan pembelajaran guided inquiry efektif ditinjau dari kemampuan penalaran siswa. Hal ini disebabkan karena dalam setiap kegiatan pembelajaran guided inquiry melibatkan siswa aktif. Kegiatan pembelajaran yang diawali dengan pemberian kerangka konseptual oleh guru sebagai fokus pembelajaran. Guru menarik perhatian siswa agar terfokus dengan permasalahan yang dihadapi. Kefokusan siswa terhadap masalah memudahkan guru mengajak keterlibatan siswa. Keterlibatan siswa ini dimanfaatkan oleh guru dengan memberikan contohcontoh dalam kehidupan sehari-hari yang berkaitan dengan permasalahan agar mampu memahami dengan baik. Siswa di arahkan pemikirannya untuk memahami dan membandingkaan contoh-contoh tersebut. Hal ini bertujuan untuk mengetahui sejauh mana kemampuan awal siswa dalam memahami permasalahan. Siswa diberikan pertanyaan-pertanyaan yang spesifik yang mengarah pada pokok permasalahan. Dari jawaban yang diperoleh, siswa mampu menemukan konsep dan membuat generalisasi sendiri. Siswa berdiskusi dalam memberikan tanggapan, pertanyaan, dan bahkan jawaban terkait dengan permasalahan. Guru membimbing siswa agar konsep yang ditemukan sesuai dengan tujuan yang tertulis dalam Lembar Kegiatan Siswa (LKS). Di dalam kegiatan LKS peneliti juga menggunakan media berupa dadu, kartu bridge, dan uang koin sehingga media ini mampu membantu kemampuan penalaran siswa. Kegiatan diskusi yang dilakukan oleh siswa mulai dari pemahaman masalah hingga pada penemuan konsep. Guru memberikan soal latihan untuk dikerjakan secara inidividu. Siswa mengerjakan soal latihan sendiri, kemandirian belajar siswa dalam kegiatan pembelajaran guided inquiry sangat ditekankan dan diawasi. 


\section{Pythagoras, 10 (2), Desember 2015 - 196}

Sardin

Berkaitan dengan keefektifan pembelajaran guided inquiry ditinjau dari sikap siswa terhadap matematika. Hal ini disebabkan karena dalam kegiatan pembelajaran guru menggunakan media pembelajaran seperti dadu, kartu bridge, uang logam, serta media-media lain yang berkaitan dengan permasalahan. Hal ini menjadikan siswa terlibat aktif dalam kegiatan pembelajaran. Keterlibatan langsung oleh siswa mulai dari awal pembelajaran hingga akhir pembelajaran. Di awal pembelajaran siswa fokus terhadap kerangka konseptual yang diberikan guru, siswa mampu memahami contoh-contoh, menemukan konsep, membuat generalisasi. Sedangkan keterlibatan siswa diakhir pembelajaran siswa mampu menerapkan konsep yang ditemukan dengan baik. Pada setiap kegiatan guided inquiry setiap siswa diberi tanggung jawab dan berperan dalam mengerjakan LKS. Siswa satu sama lain saling berdiskusi, terhadap permasalahan yang telah mereka pahami. Keterlibatan langsung oleh siswa dalam kegiatan pembelajaran guided inquiry dapat membantu siswa dalam bersikap ilmiah sehingga dapat berkontribusi positif pada prestasi belajarnya (Ergül, et al, 2011, p.63).

Berdasarkan hasil uji hipotesis diketahui bahwa siswa yang mendapat pembelajaran dengan pendekatan problem solving ditinjau dari prestasi belajar adalah efektif. Hal ini disebabkan karena keterlibatan siswa sangat diperhatikan. Siswa melakukan kegiatan pemecahan masalah ditiap pertemuannya. Guru menyiapkan masalah dalam kegiatan LKS, soal-soal latihan, dan soal pekerjaan rumah. Kegiatan pemecahan masalah yang diberikan guru dapat membantu siswa memahami konsep matematika. Hal ini sesuai dengan pendapat Cai \& Nie (2007, p.471) bahwa problem-solving activities in the classroom are used as an introductional approach that provides a context for student to learn and understad mathematics.

Dalam setiap kegiatan pembelajaran siswa aktif. Siswa aktif mulai dari memahami masalah, hingga mempresentasikannya di depan kelas. Siswa aktif mengerjakan soal-soal latihan yang diberikan guru. Dalam mengerjakan soal, siswa menyelesaikan dengan menggunakan langkah-langkah pembelajaran problem solving. Hal ini dapat mereka lakukan sebagai hasil dari keseriusannya dalam menyelesaikan langkahlangkah penyelesaian soal dalam Lembar Kegiatan Siswa (LKS) problem solving. Dalam kegiatan LKS tersebut siswa diminta untuk menyelesaikan masalah sesuai dengan langkah- langkah pembelajaran problem solving. Siswa diminta mulai dari memahami masalah, merencanakan masalah, menyelesaikan masalah sesuai dengan rencana, hingga menelaah kembali jawaban yang telah diselesaikan. Dalam proses menelaah tersebut siswa berdiskusi satu sama lain.

Dalam kegiatan berdiskusi antar kelompok guru memberikan kesempatan untuk mempresentasikan hasil diskusinya di depan kelas. Hal ini dilakukan untuk mengasah kemampuan pengetahuan yang telah dimilikinya. Siswa mempersentasikan penyelesaian masalah yang terdapat dalam LKS sesuai dengan langkahlangkah pembelajaran problem solving. Kelompok lain diminta untuk memberikan tanggapan, koreksi, atau pertanyaan. Dengan kegiatan seperti ini siswa menjadi terbiasa dan terampil dalam menyelesaikan soal-soal. Sebelum kegiatan diskusi berlangsung guru terlebih dahulu membentuk kelompok-kelompok yang terdiri dari 4-5 orang siswa. Pembentukan kelompokkelompok tersebut merupakan salah satu faktor penyebab efektifnya pembelajaran dengan pendekatan problem solving ditinjau dari prestasi belajar.

Pendekatan pembelajaran problem solving efektif ditinjau dari kemampuan penalaran siswa. Hal ini disebabkan karena siswa diminta untuk menyelesaikan setiap masalah. Masalahmasalah tersebut diselesaikan dengan menggunakan langkah-langkah pembelajaran problem solving. Dalam mengerjakan soal-soal siswa bekerja secara teratur. Sehingga siswa terlatih dalam bekerja tersusun. Hal ini terjadi karena dalam setiap pertemuan guru melatih siswa dengan mengerjakan permasalahan-permasalahan dalam LKS. Di dalam LKS guru sudah menyiapkan langkah-langkah pembelajaran problem solving dalam setiap permasalahannya. Setiap permasalahan siswa diperbiasakan menulis langkah-langkah pembelajaran problem solving. Kegiatan menulis membantu siswa dalam menggunakan kemampuan penalaran dan mengingat konsep. Hal ini sesuai dengan pendapat Kenney (Kosko \& Wilkins, 2010, p.81) bahwa $a$ student's mathematical writing can illustrate their reasoning of a problem or concept. Maksudnya bahwa dengan kegiatan menulis dapat membantu menyelesaikan masalah atau mengingat konsep.

Setelah siswa dibiasakan dengan mengerjakan soal-soal dalam LKS. Kemudian untuk mengecek pemahaman siswa, guru memberikan soal-soal latihan. Siswa kemudian mengerjakan 
soal-soal latihan dengan menggunakan langkahlangkah pembelajaran problem solving. Dalam mengerjakan soal-soal siswa berdiskusi satu sama lain. Guru memberikan kesempatan kepada siswa untuk mempresentasikan hasil diskusinya di depan kelas. Kelompok lain diminta untuk memberikan tanggapan, bertanya, dan mengoreksi jawaban temannya. Dengan demikian siswa menjadi terbiasa menjelaskan hasil pekerjaannya kepada temannya. Dalam proses penjelasan tersebut siswa mempunyai keyakinan dan terampil dalam menyelesaikan soal.

Berkaitan dengan pendekatan pembelajaran problem solving efektif ditinjau dari sikap siswa terhadap matematika. Hal ini disebabkan karena keaktifan siswa dalam pembelajaran ini sangat diperhatikan. Seperti yang dijelaskan sebelumnya bahwa selama proses pembelajaran berlangsung siswa aktif dalam memberikan tanggapan, koreksi, maupun pertanyaan baik kepada guru atau kepada teman lainnya.

Keterlibatan siswa dalam pembelajaran yakni dengan diberikan LKS tiap kali pertemuan. Siswa antusias dalam menyelesaikan permasalahan-permasalahn yang terdapat dalam LKS. Setelah berdiskusi kelompok, guru memilih secara acak kelompok-kelompok untuk mempresentasikan hasil diskusinya. Hal ini dilakukan untuk mengasah rasa percaya diri siswa dan siswa dapat belajar mandiri. Secara bergantian perwakilan kelompok mempresentasikan hasil diskusinya di depan kelas. Kelompok lain diminta untuk memberikan tanggapan, koreksi, pertanyaan, bahkan jawaban apabila kelompok yang presentasi tidak mampu menjelaskan. Dengan demikian siswa merasa termotivasi untuk bisa menguasai materi dan juga siswa merasa percaya diri dalam memberikan tanggapan.

Siswa yang sebelumnya tidak terbiasa dengan kegiatan kelompok selalu belajar sendiri-sendiri. Dalam kegiatan kelompok siswa yang belum paham dengan masalah-masalah yang diberikan guru punya keinginan bertanya kepada temannya. Siswa satu sama lain saling bertukar pengetahuan, siswa cenderung aktif sesuai bimbingan guru. Belajar kelompok merupakan lingkungan belajar yang nyaman bagi siswa. Hal ini sesuai dengan pendapat Salta \& Tzougraki (Malik, et.al, 2010, p.17) bahwa "Attitude is a tendency to think, feel, and act positively or negatively toward objects in our environment. Maksudnya sikap adalah kecenderungan bertindak positif atau negatif terhadap objek di lingkungan siswa.
Berdasarkan hasil uji perbedaan sebelum perlakuan menunjukan bahwa tidak terdapat perbedaan kemampuan awal siswa baik kelompok yang diajarkan dengan pendekatan pembelajaran guided inquiry maupun kelompok yang diajarkan dengan pendekatan pembelajaran problem solving. Sedangkan perbedaan setelah perlakuan terdapat perbedaan keefektifan pendekatan pembelajaran guided inquiry dan problem solving ditinjau dari prestasi belajar, kemampuan penalaran siswa, dan sikap siswa terhadap matematika pada materi kaidah pencacahan dan peluang. Merujuk pada teori bahwa perlakuan yang diberikan yakni berbeda. Keterlibatan siswa dalam proses pembelajaran sangat penting. Dari kedua pembelajaran yang diterapkan intensitas keterlibatan siswa dalam pembelajaran berbeda. Dengan informasi ini maka dapat dilanjutkan uji univariat untuk melihat pembelajaran mana yang lebih efektif dari kedua kelompok.

Berdasarkan hasil uji lanjut univariat menunjukjan bahwa pendekatan pembelajaran guided inquiry lebih efektif dari pada pendekatan pembelajaran problem solving ditinjau dari kemampuan penalaran siswa. Secara deskripsi data kemampuan penalaran sebelum dan sesudah perlakuan menunjukan bahwa ratarata pretes dan posttest kelas yang menggunakan pendekatan guided inquiry berturut-turut sebesar 10,84 dan 17,19. Sedangkan rata-rata pretes dan posttest kelas yang menggunakan pendekatan guided inquiry berturut-turut sebesar 11,66 dan 14,28. Dari hasil ini selisih rata-rata kelas guided inquiry hampir dua kali lipat dari ratarata kelas problem solving.

Pendekatan guided inquiry lebih efektif dibandingkan dengan pendekatakan problem solving ditinjau dari kemampuan penalaran siswa. Hal ini disebabkan karena siswa yang diajar dengan pendekatan guided inquiry dan problem solving intensitas keaktifan siswa berbeda. Siswa yang diajar dengan pendekatan guided inquiry yakni guru memberikan kerangka konseptual terlebih dahulu di awal pembelajaran. Pemberian kerangka konseptual ini dimaksudkan untuk menarik perhatian siswa agar fokus dalam belajar. Kemudian guru memberikan contoh-contoh yang berkaitan dengan materi yang di ajarkan. Siswa diminta untuk memahami contoh-contoh tersebut kemudian membandingkannya. Keterlibatan siswa dalam tahap ini selalu diperhatikan.

Pemahaman siswa terhadap contoh-contoh permasalahan yang diberikan guru menjadi aspek penentu keberhasilan awal siswa. Selan- 
jutnya guru memberikan pertanyaan-pertanyaan yang spesifik. Hal ini dirancang untuk membimbing siswa mencapai pemahaman tentang konsep. Dari pemahaman tersebut siswa dapat membentuk generalisasi. Setiap tahapan dalam kegiatan pembelajaran guided inquiry tertuang dalam Lembar Kegiataan Siswa (LKS). Pada kegiatan pembelajaran guided inquiry guru juga menyediakan media pembelajaran yang relevan dengan permasalahan. Dengan media pembelajaran seperti kartu bridge, dadu, dan uang logam, pikiran siswa jadi lebih terbuka. Sehingga dalam menyelesaikan setiap permasalahan dalam LKS siswa menjadi aktif. Selain memperhatikan penjelasan guru, siswa juga dapat berdiskusi untuk saling membantu satu sama lain.

Selain kegiatan diskusi sesama kelompok, guru juga memberikan kesempatan kepada perwakilan kelompok untuk mempresentasikan hasil diskusinya. Hal ini dimaksudkan siswa yang berkesempatan untuk menjelaskan kepada temannya mengasah kemampuan, meyakinkan kepada orang lain terhadap apa yang telah dipahaminya. Siswa lain diberi kesempatan untuk memberikan tanggapan, koreksi, atau pertanyaan. Dalam proses ini siswa saling beradu argumen. Dengan demikian siswa termotivasi untuk memahami konsep, terampil, dan terbiasa dalam mengungkapkan pendapat yang meyakinkan kepada orang lain.

Setelah kegiatan presentasi kelas, siswa dilatih kemampuan pemahaman konsep yang ditemukan dengan diberikan soal-soal latihan dan soal Pekerjaan Rumah (PR). Pada saat menyelesaiakan soal latihan maupun PR siswa menerapkan konsep yang dipahami. Hal ini terus diberikan dalam setiap pertemuan. Dalam penerapakan kegiatan pembelajaran penemuan terbimbing pada langkah ketiga fase konvergen guru membimbing siswa membuat generalisasi dari konsep yang siswa pahami (Eggen \& Kauchak, 2012, p.190). Hal ini sejalan dengan pengertian penalaran matematika siswa. Selain itu, Hal ini juga didukung oleh hasil penelitian yang diungkapkan oleh Maikristina, Dasna, \& Sulistina (2013, p.7) yang melakukan penelitian di SMA menyimpulkan bahwa keterampilan proses sains dengan mengajarkan model pembelajaran inkuiri terbimbing lebih baik daripada siswa yang dibelajarkan dengan menggunakan model problem solving.

\section{SIMPULAN DAN SARAN}

\section{Simpulan}

Berdasarkan hasil analisis data dan pembahasan, dapat disimpulkan beberapa hal; pendekatan pembelajaran guided inquiry dan pembelajaran problem solving masing-masing efektif ditinjau dari prestasi belajar, kemampuan penalaran siswa, dan sikap siswa terhadap matematika. Pendekatan pembelajaran guided inquiry sama efektifnya dengan pembelajaran problem solving ditinjau dari prestasi belajar dan sikap siswa terhadap matematika. Pendekatan pembelajaran guided inquiry lebih efektif dari pada pembelajaran problem solving ditinjau dari kemampuan penalaran siswa.

\section{Saran}

Beberapa saran yang dapat peneliti berikan untuk menjadi perhatian ke depan bagi pemerhati pendidikan. Adapun sarannya adalah sebagai berikut; Guru disarankan menggunakan pendekatan pembelajaran guided inquiry dan problem solving. Karena kedua pembelajaran tersebut efektif dalam penerapannya jika ditinjau dari aspek prestasi belajar, kemampuan penalaran, dan sikap siswa terhadap pelajaran matematika khususnya pada pokok bahasan kaidah pencacahan dan peluang. Apabila dalam hal ingin mengetahui kemampuan penalaran siswa khususnya pada pokok bahasan kaidah pencacahan dan peluang. Guru disarankan untuk menggunakan pendekatan pembelajaran guided inquiry. Untuk penelitian selanjutnya apabila menggunakan pendekatan pembelajaran guided inquiry dan/atau pendekatan pembelajaran problem solving untuk meningkatkan prestasi belajar dan/atau sikap siswa terhadap matematika disarankan untuk lebih memperhatikan atau mengontrol aktivitas siswa di dalam kelas.

\section{DAFTAR PUSTAKA}

Cai, J \& Nie, B. (2007). Problem solving in Chinese mathematics education: research and practice. [Versi Elektronik]. Original article. ZDM Mathematics Education. 39:459-473

Dehyadegary, E., et al. (2012). Academic engagement as a mediator in relationships between emotional intelligence and academic achievement among adolescents in kerman-iran [Versi electronik]. Journal of American Science, 8, 9, 823-832. 
Depdiknas. (2013). Lampiran peraturan menteri pendidikan dan kebudayaan nomor 65 tahun 2013, tentang standar proses pendidikan dasar dan menengah. Jakarta: Kemendikbud

Eggen \& Kauchak (2012). Strategi dan model pembelajaran. Mengajarkan konten dan keterampilan berpikir. Terjemahan Satrio Wahono. Boston: Pearson (Buku asli terbitan tahun 2012).

Ergül, R. et.al (2011). The effects of inquirybased science teaching on elementary school students' science process skills and science attitudes. [Versi Elektronik]. Bulgarian Journal of Science and Education Policy (BJSEP), Volume 5, Number 1, 2011, 48-68.

Forgan, J.W. (2003). Teaching problem solving through children's literature. Westport, CT: Greenwood publishing group.

Gable, R.K. (1986). Instrument development in the affective domain. Boston, MA: Kluwer-Nijhoff Publishing.

Hosnan, M.. (2014). Pendekatan saintifik dan kontekstual dalam pembelajaran abad ke 21. kunci sukses implementasi kurikulum 2013. Bogor: Ghalia Indonesia.

Ihedioha, S.A \& Osu, B.O. (2012). Comparative effectiveness of inductive inquiry and transmitter of knowledge models on secondary school students' achievement on circle geometry and trigonometry. [Versi Elektronik]. Bulletin of society for mathematical services and standards. ISSN: 2277-8020. Vol. 1 No. 3 (2012), pp. 33-46.

Ike, G. (2014). The effects of inquiry problem on students construction of mathematical reasoning and viable arguments. (Versi Elektronik]. Bowling Green State University. Honors Projects. Spring.

Jacobsen, D. A., Eggen, P., \& Kauchak, D. (2009). Methods for teaching (metodemetode pengajaran): meningkatkan belajar siswa tk-sma. (Terjemahan Achmad Fawaid \& Khoirul Anam). Upper Saddle River: Pearson Education, Inc. (Buku asli diterbitkan tahun 2009).

Johnson, B. \& Christensen, L. (2008). Educational research: quantitative, qualitative, and mixed approaches $\left(3^{\text {rd }}\right.$ ed.). Thousand Oaks, Clf: Sage Publications, Inc.

Johnson, R.A \& Wichern,W.D. (2007). Applied multivariate statistical analysis (sixth edition). Upper Saddle River, New Jersey: Pearson prentice hall.

Junaidi. (2012). Perbandingan keefektifan pembelajaran matematika dengan pendekatan open ended dan problem solving ditinjau dari sikap siswa terhadap matematika dan kemampuan pemecahan masalah matematika di kelas X SMAN 1 Pringgarata lombok tengah tahun 2011/2012. Tesis magister, tidak dipublikasikan, Universitas Negeri Yogyakarta, Yogyakarta.

Kennedy, L. M., Tipps, S., \& Johnson, A. (2008). Guiding children's learning of mathematics $\left(11^{\text {th }} e d\right.$.). Belmont, CA: Thomson Wadsworth.

Kosko, K.W \& Wilkins, L.M.J (2010). Mathematical communication and its relation to the frequency of manipulative use. [Versi Elektronik]. International Electronic Journal of Mathematics Education. Volume: 5, Number: July 2010, 79-90.

Kuhlthau, C. C., Maniotes, L. K., \& Caspari, A.K. (2007). Guided inquiry: Learning in the 21st Century (libraries unlimited guided inquiry) 1st Edition. London, E. British library catalouing.

Maikristina, N., Dasna, I. W., \& Sulistina, O. (2013). Pengaruh penggunaan model pembelajaran inkuiri terbimbing terhadap hasil belajar dan keterampilan proses sains siswa kelas XI IPA SMAN 3 Malang pada materi hidrolisis garam. Artikel. Diambil pada tanggal 4 Mei 2015 di

https://US:official\&q=pembelajaran+inku iri+terbimbing+lebih+baik+dari+pembela jaran+problem+solving

Majid, A. (2014). Implementasi kurikulum 2013. Kajian teori dan praktis. Bandung: Interes media.

Malik, M.A, et al. (2010). Effect of Problem solving teaching strategy on 8 th Grade students' attitude towards Science.[Versi Elektronik]. Journal of Education and Practice. Vol 1, No 3, 2010, 16-27 
Markaban. (2008). Model penemuan terbimbing pada pembelajaran matematika SMK. (Versi Elektronik). Yogyakarta: P4TK, Dinas Pendidikan Nasional.

Mattew, B.M., \& Kenneth, I.O. (2013). A study on the effects of guided inquiry teaching method on students achievement in logic. [Versi Elektronik]. International Researcher. Volume No.2 Issue No. 1 March 2013, 134-140.

Mohamed, L., \& Waheed, H. (2011). Secondary students' attitude towards mathematics in a selected school of maldives. [Versi Elektronik]. International journal of Humanities and social science, Vol. 1 No. 15, 277-281.

NCTM. (2000). Principles and standards for school mathematics. Reston, VA: National Concil of Theacer of Mathematics.

Polya, G. (1973). How to solve it: A new aspect of mathematical method $\left(2^{\text {nd }} \mathrm{ed}\right)$. Princeton, New Jersey: Princeton university press.

Popham, W.J. (1995). Classroom assessment. what teacher need to know. Los Angeles, USA: Allin and Bacon A simon \& Schuter Company.

Posamentier, A.S., Smith, B.S \& Stepelman,J. (2010). Teaching secondary mathematics techniques and enrichment units (eight ed). Boston, MA: Pearson Education,Inc

Rencher, A. C. (1998). Multivariate Statistical Inference and Applications. New York: A Wiley-Interscience Publication. John Wiley \& Sons, Inc

Saputra, I. (2012). Perbandingan keefektifan pendekatan investigasi matematika dan problem solving ditinjau dari pemahaman dan sikap siswa terhadap matematika pada pembelajaran matematika kelas $\mathrm{X}$ SMAN 1 Pringgarata Lombok Tengah. Tesis magister, tidak dipublikasikan, Universitas Negeri Yogyakarta. Yogyakarta.

Shadiq, F (2004) Pemecahan masalah. penalaran, dan komunikasi. Yogyakarta: Departemen Pendidikan Nasional Direktorat Jendral Pendidikan Dasar dan Menengah Pusat Pengemabangan Penataan Guru (PPPG) Matematika Yogyakarta. Makalah disajikan dalam diklat/pengembang matematika SMP jenjang dasar, di PPPG matematika Yogyakarta.

Skemp, R,R. (1971). The psychology of learning mathematics. Victoria, Australia: Penguin books Australia ltd.

Syah, M (2008). Psikologi pendidikan dengan pendekatan baru. Bandung: PT.Remaja Rosdakarya.

Zahman, A. (2012). Keefektifan pendekatan kontekstual dan pendekatan pemecahan masalah pada pembelajaran matematika ditinjau dari pencapaian kompetensi dasar, kemampuan penalaran, dan komunikasi matematika. Tesis magister, tidak diterbitkan, Universitas Negeri Yogyakarta, Yogyakarta.

Zukri, N.O. (2013). Keefektifan pembelajaran matematika dengan pendekatan problem solving dan penemuan terbimbing ditinjau dari prestasi, motivasi, dan minat belajar siswa SMP muhammadiyah 2 Yogyakarta. Tesis magister, tidak diterbitkan, Universitas Negeri Yogyakarta, Yogyakarta. 